https://helda.helsinki.fi

\title{
Relativism in the Philosophy of Anthropology
}

\section{Koskinen, Inkeri}

Routledge

2019

Koskinen , I 2019 , Relativism in the Philosophy of Anthropology . in M Kusch (ed.), The

Routledge Handbook of Philosophy of Relativism . , 45 , Routledge Handbooks in

Philosophy, Routledge , pp. 425-434 .

http://hdl.handle.net/10138/330646

acceptedVersion

Downloaded from Helda, University of Helsinki institutional repository.

This is an electronic reprint of the original article.

This reprint may differ from the original in pagination and typographic detail.

Please cite the original version. 


\title{
Relativism in the philosophy of anthropology
}

\author{
Inkeri Koskinen
}

\begin{abstract}
This chapter explores arguments, ideas and practices related to relativism in social and cultural anthropology. It covers discussions about cultural relativism, methodological relativism, conceptual relativism, relativism about rationality, moral relativism, epistemic relativism, and ontological relativism.
\end{abstract}

\section{Introduction}

An article on relativism in the philosophy of anthropology should cover two quite different perspectives on its topic. On the one hand, it must deal with arguments presented by philosophers, and on the other, with ideas and practices developed by anthropologists. Sometimes the two perspectives complement each other. Both anthropologists and philosophers have taken part in some of the same debates about relativism; philosophers' arguments have influenced anthropological theory and ethnographic research practices; and ideas developed in anthropology have inspired philosophical discussions. On other occasions, however, there has been little communication across disciplinary boundaries, and sometimes the communication has been ridden with misinterpretations.

I will mostly focus on arguments presented in the tradition of analytic philosophy, and on ideas and practices developed in social and cultural anthropology. For the past few decades, however, connections between anthropological theory and philosophy have largely happened through continental thinkers. I will explore the rather fragmented interactions between the mainstream of professional philosophy and this literature. Within these limits, this chapter covers roughly a century's worth of discussions and debates. 


\section{Relativism in anthropology}

Popular conceptions of anthropology often take cultural relativism to be its sine qua non. But though it is still a necessary part of any undergraduate anthropology curriculum, in the writings of contemporary anthropologists it is hard to find the thoroughgoing cultural relativism endorsed in the American cultural anthropology in the 1940 s and 50 s.

Cultural relativism became an important idea in anthropology in a specific social and intellectual context. It was developed as an important part of the criticism directed against the evolutionary views of nineteenth-century anthropologists such as James Frazer and Edward Tylor. Franz Boas and his students, following similar ideas presented in Europe, rejected as ethnocentric and racist the way in which the evolutionists classified cultures on a scale ranging from primitive to modern (Westermarck 1932; Boas 1940; Benedict 1934; Herskovits 1955). According to these critics, anthropologists should be wary of using their own cultural norms when evaluating the cultures they study. In other words, from the well-documented relativity of e.g. moral judgements and epistemic practices, they proceeded to the relativistic claim that anthropologists could or should not move beyond this relativity.

The multifaceted and often unclear idea of cultural relativism was formulated most radically in the writings of Boas' students, particularly Melville Herskovits, who emphasised "the validity of every set of norms for the people whose lives are guided by them" (Herskovits 1948, 76), and formulated the most cited definition of cultural relativism: "Judgements are based on experience, and experience is interpreted by each individual in terms of his own enculturation." (Herskovits 1955, 15.)

Cultural relativism was met with immediate criticism (e.g. Williams 1947; Kluckhohn 1955). The most common worry was that it would lead to moral nihilism. After Herskovits, it is hard to fine anyone who endorsed a full-blown form of it. For instance, Clifford Geertz, in his interpretivist reading of cultural relativism, defends it 
to a certain degree, but also notes its shortcomings: "The truth of the doctrine of cultural (or historical - it is the same thing) relativism is that we can never apprehend another people's or another period's imagination neatly, as though it were our own. The falsity of it is that we can therefore never genuinely apprehend it at all." (Geertz 1983, 44; see also Geertz 1984.)

Cultural relativism is linked to several other, sometimes conflicting forms of relativism. Moreover, at least one form of relativism that rejects the idea of culture has recently been defended in the anthropological literature.

Let us loosely characterise relativism as the claim that the propositions of a certain domain (such as knowledge, ethics, or rationality) are true or false only relative to an underlying set of standards, of which there can be several. Moreover, such sets of standards must not be ranked, and one cannot choose between different sets on the basis of a neutral rational comparison (Kusch 2016). The often-noted ambiguity of cultural relativism stems from its definition only mentioning the framework encompassing a set of standards: culture. It is not clear what domains exactly it is supposed to cover. When also the domain is named, cultural relativism gets disintegrated. We can distinguish several forms of relativism where culture is often named as the overarching framework to which propositions of some domain are relative.

Here I will focus on the following forms of relativism: 1) Conceptual relativism, according to which conceptual frameworks are or can be incommensurable, and they shape human thought so thoroughly that statements made in two different conceptual frameworks cannot be meaningfully compared. 2) Relativism about rationality, according to which judgements of rationality are relative to a framework, and there is no neutral criterion of rationality. 3) Moral relativism, according to which moral judgements are relative to some framework, and there is no neutral criterion for adjudicating between conflicting moral judgements made in different domains. 4) Epistemic relativism, according to which there are several knowledge systems, and there is no neutral criterion for adjudicating between conflicting claims 
made in different systems. And finally 5) ontological relativism, according to which there are many different ontologies in which different kinds of objects emerge, and there is no one privileged ontology. As we shall see, the proponents of this form of relativism (if it indeed is a form of relativism) usually reject the notion of culture, thus breaking with cultural relativism altogether.

Before focusing on discussions and debates around these forms of relativism, it is however necessary to note that in anthropology, questions about relativism arise first and foremost in the context of ethnographic practice.

\section{Methodological relativism in ethnography}

Even though no single, well-defined relativistic stance can be claimed to be generally accepted in anthropology, a form of methodological relativism is very common. Ethnographers generally avoid the appraisal of their informants' knowledge claims and moral views. Even a harsh critic of cultural relativism such as lan Jarvie agrees that if cultural relativism is interpreted purely as a methodological approach, a crucial factor of which is the suspension of judgement and censure, it "is co-terminus with good anthropology" (Jarvie 2006, 582).

Many misunderstandings between philosophers and anthropologists originate from different approaches to questions about relativism. Philosophers are typically interested justifying philosophical stances. But in modern anthropology questions about relativism surfaced for practical and methodological reasons. With the rejection of evolutionary hierarchies, anthropologists had to accommodate the antiracist conviction that there was but a single humanity, with the radical diversity evident for any ethnographer (Boas 1940; Haines 2007; Theunissen 2017). And methodological relativism offers a solution to a number of issues that arise in ethnographic practice: one must avoid ethnocentric bias, show respect to the informants, and refrain from hasty interpretations, as they could lead to 
misunderstandings. It is a practice rather than a stance, a way to encounter the observed radical differences without diminishing them.

The suspension of judgement is, however, limited in scope. Anthropologists typically treat the views of their colleagues very differently from those of their informants: colleagues do face criticism. Talal Asad has expressed this practical difference aptly when reflecting on a disagreement with Ernst Gellner: "In taking up a critical stance toward his text I am contesting what he says, not translating it, and the radical difference between these two activities is precisely what I insist on." (Asad 1986, 156.)

\section{Conceptual relativism and cultural translation}

Foreign people and their exotic mores have throughout the times inspired relativistic musings, and for the past century, fictional anthropologists and linguists attempting to understand alien cultures and languages have often appeared in philosophical thought experiments. One of the best-known ones was presented by Willard Van Orman Quine in 1960. He describes a linguist who attempts to understand the language of a hitherto not contacted people, and calls the task that of radical translation. The example of the linguist in an unlikely situation is used to make a philosophical point about the indeterminacy of translation: the linguist can never be sure of having correctly translated the utterances of the people he studies, as many incompatible conceptual schemes can account for their verbal behaviour. As Quine (1960) notes, the doctrine of indeterminacy of translation will sound familiar to readers acquainted with Ludwig Wittgenstein's remarks on meaning. Wittgenstein argued that meaning cannot be private; that it is constituted by the public use of words; and that we cannot understand individual sentences of a language without understanding the language as a whole (Wittgenstein 1953; 1958).

The idea of languages where each sentence has meaning only as a part of a whole framework, together with the idea that we have no way of assessing whether we 
have succeeded in translating between two languages, can be interpreted in a way that leads to conceptual relativism. A linguistic and cultural variant of such relativism would claim that conceptual frameworks are tied to natural languages, that natural languages are integral parts of human cultures, and that statements made in two different cultures cannot be meaningfully compared. And a form of relativism following similar lines, though emphasising also a link between language and world view, had already been developed in anthropology and linguistics. It is often ascribed to Boas's student Edward Sapir (1929), and his student Benjamin Whorf (1956; see also Hoijer 1954), and referred to as the Sapir-Whorf Hypothesis, even though they never formulated any thesis together. Sapir stressed the differences between different languages and argued that language influences human thought. Whorf continued by suggesting that the differences between different languages lead to drastically different ways of thinking and perceiving: "the world is presented in a kaleidoscopic flux of impressions which has to be organized by our minds-and this means largely by the linguistic systems in our minds" (Whorf 1956, 213).

Later, philosophical ideas about conceptual schemes and translation became influential in interpretative anthropology where ethnography was often understood as cultural translation. Ethnographers of course could not accept a total lack of translatability between different cultures. However, as Geertz (1973; see also Risjord 2007) realised, combined with hermeneutical views of understanding, Wittgensteinian ideas could be used to justify established ethnographic practices. And thus Geertz stressed that culture is public and observable, not private. And even if the ethnographer's language differs from the language used in the culture the ethnographer studies, the former language could be expanded in a way that made it possible to translate expressions that originally gained their meaning in the latter.

Also philosophers have repeatedly rejected strong forms of conceptual relativism. The best-known argument against conceptual relativism was presented by Donald Davidson (1974). He claimed that the idea of alternative, incommensurable conceptual schemes is untenable: for the schemes to be truly incommensurable, we must fail to translate between them. But if translation fails, we have no reason to 
claim that what we are attempting to translate is in fact a language, not just random noise. It follows that to identify something as language, we have to be able to translate it. Davidson further argues that if we are faced with the task of radical translation, we have no other option than to adopt the principle of charity: we must assume that the speakers whose words we attempt to translate are rational and share some beliefs with us. This is because we cannot assign meanings to utterances without knowing the speakers beliefs, nor can we learn the beliefs without understanding what the utterances mean. According to Davidson, the only way out of the impasse is to assume a common rationality and some shared beliefs. (Davidson 1974; see also Henderson 1987; Risjord 2000.)

\section{Rationality and relativism}

The so-called "rationality and relativism debates" were sparked by Wittgensteinian ideas about language and rationality, and especially by Peter Winch's famous article "Understanding a Primitive Society" (1964; see also Winch 1958). Both Wittgenstein and Winch maintained that we must question not only the applicability of our familiar concepts, but also our norms of rationality, when evaluating alien cultures. Wittgenstein (1967) found fault with James Frazer for treating religious practices as mistakes, whereas Winch turned his critical eye towards Evans-Pritchard's (1937) famous ethnography of the South-Sudanese Azande.

Winch pays particular attention to a set of Zande beliefs that Evans-Prichard claimed were formally inconsistent. The clearest case of apparent irrationality he describes is related to Zande witchcraft. The Azande held that one can identify a witch through the use of a poison oracle, and that the substance that causes withcraft is inherited from fathers to sons and from mothers to daughters. In other words, a positive result from the poison oracle would implicate a whole paternal or maternal line of descent. And if the number of positive results were high enough, they should prove that all living Azande were witches. But according to Evans-Prichard $(1937,24)$

"Azande see the sense of the argument but they do not accept its conclusions". 
Winch argued that it is wrong to assume that the Azande were doing something comparable to scientific explanation and confirmation of hypotheses: "Oracular revelations are not treated as hypotheses and, since their sense derives from the way they are treated in their context, they therefore are not hypotheses" (Winch 1964, 312). The apparent irrationality of the Zande beliefs is a result of EvansPrichard using our familiar standards of rationality when assessing Zande thought. (Winch 1964; see also Winch 1958.)

Winch's views provoked objections, leading to a lengthy controversy. Its key papers have been published in two collections (Wilson 1970; Hollis and Lukes 1982). The debate was understood to be between two positions: relativism versus a position that treats rationality as universal. Philosophers, anthropologists and sociologists agreed that there is something of a shared core rationality; though there was no agreement on the nature and core features of such rationality. The debate remained closely connected to philosophical questions about translation, as the central problem of apparent irrationality was thought to arise when interpretation fails. Some appealed to arguments in the proximity of Davidson's (1974) "principle of charity": if we are to understand foreign cultures, we must attribute some shared principles of rationality to them.

Some anthropologists, particularly cognitive anthropologists (e.g. Sperber 1982), took part in the debate, arguing against Winch's views. But many of the philosophers engaged in the debate mainly used the threat of relativism as a foil in their defences of different conceptions of rationality, which may not have been conducive to much engagement with anthropology. And the anthropological reaction to the whole controversy was at times fairly critical towards all parties. This was because many anthropologists found the philosophers' general disregard for empirical facts disconcerting. For instance, according to Ernest Gellner (1968) Evans-Pritchard liked toonce pointed out that both Winch and Winch's critic, Alasdair Maclntyre, wrongly referred to cattle in Azande culture. The Azande do not have cattle. 


\section{Moral relativism and human rights}

In anthropology discussions about cultural relativism have focused much more on moral issues. The debate about cultural relativism understood as moral relativism started in 194 when the American Anthropological Association published a critical statement on the UN's Universal Declaration of Human Rights. The statement's main author was Herskovits. Some of the key points of the criticism were that as the declaration privileged individual rights; that it ended up disregarding colonial cultural oppression; and that respect for cultural differences demanded the acceptance of different moral codes: "Standards and values are relative to the culture from which they derive so that any attempt to formulate postulates that grow out of the beliefs or moral codes of one culture must to that extent detract from the applicability of any Declaration of Human Rights to mankind as a whole." (AAA 1947, 542.)

The anthropological community's reaction to the association's statement has often been described as embarrassment. The reason for embarrassment, however, has undergone changes over the years. In their initial comments H.G. Barnett (1948) and Julian H. Steward (1948) did question the moral viability of the statement's overarching tolerance, but were more concerned with its lack of scientific rigor. Steward $(1948,351)$ concluded that "the Statement is a value judgment any way it is taken", and thus jeopardised the association's reputation as a scientific organisation. Later, especially when some human-rights violators had invoked the kind of moral relativism the statement endorsed, the focus shifted to worries about moral nihilism (Geertz 1984; Engle 2001).

Compared with the original declaration, the current human-rights discourse is less dominated by Western legal thought, and worries about cultural rights resembling some of the ones expressed in the 1947 statement have been brought up by thinkers from developing countries, as well as by representatives of indigenous peoples. Over the years many anthropologists have lamented that the 1947 statement prevented anthropological involvement in discussions about human rights. Many attempts have been made to formulate positions that would make anthropological viewpoints 
taken more into account in the human-rights discourse. Finally in 1999, the AAA adopted a declaration on anthropology and human rights, which the association's Human Rights Committee has called a "complete turnaround" from the stance taken in the 1947 statement (AAA 1999; Engle 2001; Goodale 2006; Brown 2008).

\section{Epistemic relativism in the postcolonial critique of anthropology}

Postcolonial theory is often ambivalent in its treatment of relativism. From the literature it is easy to find both statements that sound fiercely relativistic, and statements that are resolutely antirelativist. These latter positions have often been overlooked by the critics of overtly political or "postmodern" theorizing. For instance Paul Boghossian claims that in many fields in the humanities and the social sciences it is by now orthodoxy to claim that there are "many radically different, yet 'equally valid' ways of knowing the world, with science being just one of them" (Boghossian $2006 a, 2)$. Some of his examples point towards postcolonial theory, and indeed, notions such as "alternative epistemologies" and "different ways of knowing" abound in postcolonial literature. They are sometimes interpreted as expressions of postmodern epistemic relativism (mainly called so by its critics). This Nietzschean and Foucauldian form of relativism takes knowledge to be always perspectival, partial and tied to power structures: it is the dominant social group or culture that gets to set its own criteria for assessing knowledge claims as universally valid (Baghramian 2004, 79-88; Foucault 1977/1980).

Postcolonialism is overtly political. Already in early key works (Fanon 1952; Deloria 1969; Said 1978), a part of the political criticism was directed towards Western science, and particularly anthropology, which was claimed to have served colonial rule. But while science is criticised, the focus in the multifaceted postcolonial literature is usually on social injustices colouring every aspect of the lives of the oppressed, the demand for liberation, and the development of new, more socially just research methods. Not on the formulation or defence of some relativistic stance. And indeed, rather than on relativism, the countercriticism in anthropology 
has focused on cultural essentialism and the reintroduction of the romantic notion of "the native" (Kuper 2003; McGhee 2008).

In fact, the political aims of postcolonial theory can lead to antirelativism. Influenced by critical theory and feminist philosophy, some postcolonial thinkers embrace Marxist forms of universalism, and some reject epistemic relativism in a way that echoes arguments presented in standpoint theory (see Figueroa and Harding 2003; Harding 2011). For instance, Boaventura de Sousa Santos argues in his influential book Epistemologies of the South that "epistemicide" is an integral part of systematic colonial oppression. According to him, scientific knowledge is limited in ways that prevent it from grasping "the inexhaustible diversity of the world" (Santos $2014,108)$. He argues that different epistemologies, particularly ones endorsed in the emancipatory movements of the "global South," should complement scientific knowledge. But he rejects epistemic relativism as an unsuitable position for anyone striving for social emancipation: "If all the different kinds of knowledge are equally valid as knowledge, every project of social transformation is equally valid or, likewise, equally invalid." (Santos 2014, 190.)

So the claim that there are multiple epistemologies or knowledge systems can be interpreted as pluralistic rather than relativistic (see Chang, this volume). However, such postcolonial pluralism does not always extend to science. As Arun Agrawal (1995) has noted, mistrust in science has led many postcolonial critics to treat science as a single, coherent knowledge system, opposed by the multitude of oppressed knowledge systems. Nevertheless, the aim of many postcolonial scholars is to integrate science more closely with Southern, indigenous etc. knowledge systems, and to develop decolonised research methods. Still, power asymmetries are often taken to impede such integration, as the marginalised knowledge systems can easily get either misrepresented, or as in e.g. ethnomedicine, commercially exploited. (Smith 1999; Denzin et. al 2008; Ludwig 2016.)

The postcolonial critique of science and the development of postcolonial methodology have engendered new forms of research, such as indigenous activist 
research. In anthropology, they have altered ethnographic research practices. Coresearch and participatory projects, where anthropologists collaborate with representatives of the people they study, have become more common. As I have argued elsewhere (Koskinen 2014), these developments challenge methodological relativism in anthropology. When informants become co-researchers in participatory projects, suspension of judgement is no longer an either epistemically or ethically viable attitude towards their views.

\section{Ontological relativism and anthropology without culture}

The central role that the concept of culture has long held in anthropology has been questioned in many ways during the past fifty years. The influences of Marxism and postcolonialism, and in 1986 the publication of Writing Culture (Clifford \& Marcus 1986), a seminal collection of essays addressing the rhetorical techniques ethnographers use to establish their epistemic authority, added to an already existing uneasiness. Ethnographies depicted unified cultures, thus hiding conflicts from view. Moreover, as Roy Wagner (1975) had noted, if concepts gained their meaning in their cultural contexts, then surely this applied also to the concept of culture. And indeed, for instance Marily Strathern (1980) has claimed that the Hagen no not have anything resembling our distinction between the invariant nature on the one hand and culture as human elaboration upon it on the other. Ethnographers had to consider the possibility that the concept of culture might not be in any meaningful way applicable to the people they study, and that using it might be misleading (Kuper 1999; Risjord 2007).

The recent "ontological turn" in anthropology has added new arguments to the arsenal of the anthropologists who wish to do away with the concept of culture. Not only do the ontological anthropologists prefer to use local concepts instead of overarching ones - such as culture - but they have questioned the whole representationalist idea embedded in the notion of culture. According to these critics, both cognitive and interpretative anthropological theories agree that there is 
one world, which different cultures represent in diverse ways. This dualist position is what the ontological turn rejects. Anthropology is not translation between worldviews or cultures (Henare, Holbraad \& Wastell 2007; Sivado 2015; Holbraad \& Pedersen 2017; Heywood 2017).

In practice, the aim is "to take things encountered in the field as they present themselves, rather than immediately assuming that they signify, represent, or stand for something else" (Henare, Holbraad and Wastell 2007, 2). And instead of focusing on speech and human interactions, ontological anthropology pays attention to the different objects that emerge in different human-nonhuman interactions. Many of its proponents reject the idea of matter and ideas as distinct categories, often citing Gilles Deleuze's and Bruno Latour's ideas. This leads to talk about plural ontologies.

It is not entirely clear whether the ontological turn entails ontological relativism. As Martin Paleček and Mark Risjord (2012) note, ontological anthropologists hold that different objects emerge in different networks of interaction, and no ontology is privileged over others. However, the view can also be interpreted as perspectivism, or as David Ludwig (2018) has argued, pluralism. But if it is interpreted as a form of relativism, then from a philosophical point of view it is an interesting one. Paleček and Risjord claim that it is immune to the Davidsonian critique, which rests largely on the principle of charity and the identification of incommensurability with a failure of translation. The ontological anthropologists explicitly reject the idea of anthropology as translation, as well any representationalist distinction between scheme and content. So if the view is interpreted as a form of relativism, it could spur new philosophical debates about relativism in anthropology.

\section{Literature}

Agrawal, Arun. 1995. Dismantling the divide between indigenous and western knowledge. Development and Change, 26:3, 413-439.

American Anthropological Association. 1947. Statement on human rights. American Anthropologist 49, 539-43. 
American Anthropological Association. 1999. Declaration on anthropology and human rights. Url: <http://www.aaanet.org/committees/cfhr/ar95.htm> (last updated 2000).

Asad, Talal. 1986. The Concept of Cultural Translation in British Social Anthropology. In J. Clifford and G. Marcus (eds.), Writing Culture. Berkeley: University of California Press, 141-164.

Baghramian, Maria. 2004. Relativism. New York and London: Routledge.

Barnett, H. G. 1948. On science and human rights. American Anthropologist 50:2, $352-355$.

Benedict, Ruth. 1934. Patterns of Culture. Boston and New York: Houghton Mifflin. Boas, Fraz. 1940. Race, Language, and Culture. New York: Macmillan. Boghossian, Paul. 2006. Fear of Knowledge: Against Relativism and Constructivism. Oxford: Clarendon Press.

Brown, Michael F. 2008. Cultural Relativism 2.0. Current Anthropology 49:3, 363383.

Clifford, James and Marcus, George (eds.). 1986. Writing Culture. Berkeley: University of California Press

Davidson, Donald. 1974. On The Very Idea of A Conceptual Scheme. Proceedings and Addresses of the American Philosophical Association 47, 5-20.

Deloria, Vine, Jr. 1969. Custer Died for Your Sins: An Indian Manifesto. New York: Macmillan.

Denzin, Norman K.; Lincoln, Yvonna S. and Smith, Linda Tuhiwai. 2008. Introduction: Critical Methodologies and Indigenous Inquiry. In N. K. Denzon, Y. S. Lincoln, and L. Tuhiwai Smith (eds.) Handbook of Critical and Indigenous Methodologies. Los Angeles: Sage.

Engle, Karen. 2001. From Skepticism to Embrace: Human Rights and the American Anthropological Association from 1947-1999. Human Rights Quarterly 23, 536-559. Evans-Pritchard, Edward. 1937. Witchcraft, Oracles and Magic among the Azande. Oxford: Clarendon Press.

Fanon, Franz. 1952. Peau noire, masques blancs. Paris: Seuil. Figueroa, Robert and Harding, Sandra (eds.). 2003. Science and Other Cultures: Issues in Philosophies of Science and Technology. New York and London: Routledge. 
Foucault, Michel 1977/1980. Truth and Power. Interview with A. Fontana and P. Pasquino. In C. Gordon (ed.) Power/Knowledge: Selected Interviews and Other Writings 1972-1977, transl. C. Gordon, L. Marshall, J. Mepham and K. Soper. New York: Panthenon books, 109-133.

Geertz, Clifford. 1973. The Interpretation of Cultures: Selected Essays. New York: Basic Books.

Geertz, Clifford. 1983. Local Knowledge: Further Essays in Interpretive Anthropology. New York: Basic Books.

Geertz, Clifford. 1984. Anti Anti-Relativism. American Anthropologist 86:2, 263-278. Gellner, Ernest. 1968. The Entry of the Philosophers. Times Literary Supplement, 4 April 1968, 347-349.

Goodale, Mark. 2006. Toward a critical anthropology of human rights. Current Anthropology 47, 485-511.

Haines, Valerie. 2007. Evolutionary explanations. In S. P. Turner and M. W. Risjord (eds.), Philosophy of Anthropology and Sociology. Amsterdam and Bos- ton: Elsevier/North-Holland, 249-310.

Harding, Sandra. 2011. Other Cultures' Sciences. In S. Harding (ed.), The Postcolonial Science And Technology Studies Reader. Durham and London: Duke University Press, 151-158.

Henare, Amiria, Holbraad, Martin, and Wastell, Sari (eds.). 2006. Thinking through things: theorising artefacts ethnographically. London: Routledge.

Henderson, David K. 1987. The Principle of Charity and the Problem of Irrationality. Synthese 73 (2), 225-252.

Herskovits, Melville Jean. 1948. Man and His Works: The Science of Cultural Anthropology. New York: Alfred A. Knopf.

Herskovits, Melville J. 1955. Cultural anthropology. New York : Knopf. Heywood, Paolo. 2017. The Ontological Turn. In The Cambridge Encyclopedia of Anthropology. DOI: http://doi.org/10.29164/17ontology.

Hoijer, Harry. 1954. The Sapir Whorf hypothesis. In H. Hoijer (ed.), Language in Culture. Chicago: University of Chicago Press, 92-105.

Holbraad, Martin and Pedersen, Morten A. 2017. The ontological turn: an anthropological exposition. Cambridge: Cambridge University Press. 
Hollis, Martin and Lukes, Steven (eds.). 1982. Rationality and Relativism. Oxford: Basil Blackwell.

Jarvie, Ian. 2006. Relativism and Historicism. In S. P. Turner and M. W. Risjord (eds.), Philosophy of Anthropology and Sociology. Amsterdam and Boston: Elsevier/NorthHolland, 553-589.

Kluckhohn, Clyde. 1955. Ethical Relativity: Sic et Non. Journal of Philosophy 52, 66377.

Koskinen, Inkeri. 2014. Critical Subjects: Participatory Research Needs to Make Room for Debate. Philosophy of the Social Sciences 44:6, 707-732.

Kuper, Adam. 2003. The Return of the Native. Current Anthropology 44:3, 389-402.

Kuper, Adam. Culture: The Anthropologists' Account. Cambridge, MA: Harvard University Press, 1999.

Kusch, Martin. 2016. Relativism in Feyerabend's Later Writings. Studies in History and Philosophy of Science 57, 106-113.

Ludwig, David. 2016. Overlapping ontologies and Indigenous knowledge. From integration to ontological self-determination. Studies in History and Philosophy of Science Part A 59, 36-45.

Ludwig, David. 2018 Revamping the Metaphysics of Ethnobiological Classification. Current Anthropology 59:4, 415-423.

McGhee, Robert. 2008. Aboriginalism and The Problems of Indigenous Archaeology. American Antiquity 73:4, 579-597.

Paleček, Martin and Risjord, Mark. 2012. Relativism and the Ontological Turn within Anthropology. Philosophy of the Social Sciences 43:1, 3-23.

Risjord, Mark W. 2000. Woodcutters and Witchcraft: Rationality and Interpretive Change in the Social Sciences. New York: Suny Press.

Risjord, Mark W. 2007. Ethnography and Culture. In S. P. Turner and M. W. Risjord (eds.), Philosophy of Anthropology and Sociology. Amsterdam and Bos- ton:

Elsevier/North-Holland, 399-428.

Said, Edward. 1978. Orientalism. New York: Pantheon Books.

Santos, Boaventura de Sousa. 2016. Epistemologies of the South: Justice against epistemicide. London and New York: Routledge, Taylor \& Francis Group.

Sapir, Edward. 1929. The Status of Linguistic as a Science. Language 5, 209-212. 
Sivado, Akos. 2015. The Shape of Things to Come? Reflections on the Ontological Turn in Anthropology. Philosophy of the Social Sciences 45:1, 83-99.

Sperber, Dan. 1982. Apparently Irrational Beliefs. In M. Hollis and S. Lukes (eds.), Rationality and Relativism. Oxford: Basil Blackwell, 149-80.

Strathern, Marilyn. 1980. No nature; no culture. In C. MacCormack \& M. Strathern (eds.), Nature, culture, gender. Cambridge: University Press.

Steward, Julian H. 1948. Comments on the Statement on Human Rights. American Anthropologist 50:2, 351-352.

Theunissen, Mark. 2017. Rationality, Naturalism, and Critique in the Philosophy of Social Science. Doctoral dissertation. New York: The New School University.

Tuhiwai Smith, Linda. Decolonizing Methodologies: Research and Indigenous Peoples. London and New York: Zed Books; Dunedin, New Zealand: University of Otago Press, 1999.

Wagner, Roy. 1975. The Invention of Culture. Englewood Cliffs, NJ: Prentice-Hall. Westermarck, Edward. 1932. Ethical Relativity. New York: Littlefield, Adams \& Company.

Westermarck, Edvard. 1932. Ethical Relativity. London: Kegan Paul, Trench, Trubner. Whorf, Benjamin. 1956. Science and Linguistics. In J.B. Carrol (ed.), Language, Thought, and Reality: Selected Writing of Benjamin Lee Whorf. Cambridge, Mass: MIT Press, 207-219.

Williams, Bernard. 1974. The Truth in Relativism. Proceedings of The Aristotelian Society, New Series 75, 215-228.

Williams, Elgin. 1947. Anthropology for the Common Man. American Anthropologist 49:1, 84-90.

Winch, Peter. 1958. The Idea of a Social Science and its Relation to Philosophy. London: Routledge \& Kegan Paul.

Winch, Peter. 1964. Understanding a Primitive Society. American Philosophical Quarterly 1:4, 307-324.

Wittgenstein, Ludwig. 1953. Philosophische Untersuchungen: Philosophical investigations. Transl. by G. E. M. Anscombe. Oxford : Blackwell. Wittgenstein, Ludwig. 1958. The Blue and Brown Books. Oxford: Blackwell. 
Wittgenstein, Ludwig. 1967. Bemerkungen über Frazers The Golden Bough. Synthese $17,233-253$.

Quine, Willard Van Orman. 1960. Word and Object. Cambridge, MA: MIT Press. 